H200616

\title{
Entrepreneurship and its determinants in a cross-country setting
}

Andreas Freytag

Roy Thurik

Zoetermeer, October, 2006 
This report is published under the SCALES-initiative (SCientific AnaLysis of Entrepreneurship and SMEs), as part of the 'SMEs and Entrepreneurship programme' financed by the Netherlands Ministry of Economic Affairs.

Most recent EIM reports and much more on SMEs and Entrepreneurship can be found at: www.eim.nl/smes-and-entrepreneurship.

$\begin{array}{ll}\text { address: } & \text { Italiëlaan } 33 \\ \text { mail address: } & \text { P.O. Box } 7001 \\ & \text { 2701 AA Zoetermeer } \\ \text { telephone: } & +31793430200 \\ \text { telefax: } & +31793430201 \\ \text { website: } & \text { www.eim.nl }\end{array}$

The responsibility for the contents of this report lies with EIM. Quoting numbers or text in papers, essays and books is permitted only when the source is clearly mentioned. No part of this publication may be copied and/or published in any form or by any means, or stored in a retrieval system, without the prior written permission of EIM.

EIM does not accept responsibility for printing errors and/or other imperfections. 


\title{
Entrepreneurship and its determinants in a cross-country setting
}

\author{
Andreas Freytag ${ }^{b}$ and Roy Thurik ${ }^{a}$
}

\author{
${ }^{a}$ Centre for Advanced Small Business Economics, Erasmus University Rotterdam, P.O. Box 1738, 3000 \\ DR Rotterdam, the Netherlands, EIM Business and Policy Research, P.O. Box 7001, 2701 AA \\ Zoetermeer, the Netherlands and Max Planck Institute of Economics, Jena, Germany. \\ thurik@few.eur.nl \\ ${ }^{\mathrm{b}}$ Wirtschaftswissenschaftliche Fakultät, Friedrich Schiller Universität Jena, Carl-Zeiss-Straße 3, 07743 \\ Jena, Germany. \\ a.freytag@wiwi.uni-jena.de
}

\begin{abstract}
The relative stability of differences in entrepreneurial activity across countries suggests that other than economic factors are at play. The present paper offers some new thoughts about the determinants of entrepreneurial attitudes and activities by testing the relationship between institutional variables and cross-country differences in the preferences for self-employment as well as in actual selfemployment. Data of the 25 member states of the European Union as well as the US are used. The results show that country specific (cultural) variables seem to explain the preference for entrepreneurship but not the actual entrepreneurship. The present paper also introduces the remaining four papers of the special issue of the Journal of Evolutionary Economics around the theme Entrepreneurship and Culture.
\end{abstract}

Version: October 2006

Prepared for: Journal of Evolutionary Economics (2007)

Document: intro jee afr rth v11b.doc 10/10/2006 3:31 PM

JEL code: M13, O57, P52, Z1

Acknowledgement: The authors would like to thank Sjoerd Beugelsdijk, Isabel Grilo, Lorraine Uhlaner, Sander Wennekers, and the participants of the workshop on Entrepreneurship and Culture, Jena, February 7, 2005) for their comments. The workshop was a joint effort of the Max Planck Institute of Economics in Jena, EIM Business and Policy Research in Zoetermeer and the Economics Faculty of the Friedrich Schiller Universität Jena. This paper has been written in the framework of the research program SCALES carried out by EIM and financed by the Dutch Ministry of Economic Affairs.

Corresponding author: Roy Thurik 


\section{Introduction}

The phenomenon of entrepreneurship is present on various levels of observation such as the person or the firm, region or industry and even nation (Davidsson, 2004; Wennekers and Thurik, 1999). Moreover, the approaches to explaining the phenomenon have built on a variety of disciplines such as economics, sociology and psychology (Wennekers, Uhlaner and Thurik, 2002). In the $20^{\text {th }}$ century three scholars, Schumpeter, Kirzner and Knight, have shaped the economics literature on entrepreneurship. ${ }^{1}$

It is well-known that the level of entrepreneurship, for instance expressed as the percentage of owner/managers of incorporated and unincorporated businesses relative to the labor force, differs strongly across countries (Van Stel, 2005). This variation is related to differences in levels of economic development, but also to diverging demographic, cultural and institutional characteristics (Blanchflower, 2000; Wennekers, 2006). There is evidence of a Ushaped relationship between the level of business ownership (self-employment) and per capita income. ${ }^{2}$ Recent research in the framework of the Global Entrepreneurship Monitor (GEM) using the rate of nascent entrepreneurship or the prevalence of young enterprises shows the same phenomenon. ${ }^{3}$ Nascent entrepreneurship also reveals a wide-ranging diversity across nations and even regions. ${ }^{4}$ An explanation of this variation is much needed as many governments attach high hopes to a positive effect of entrepreneurship on economic growth and, as a consequence, try to promote new business start-ups.

Whereas a number of individually relevant determinants of entrepreneurship is widely explored (Parker, 2004; Grilo and Irigoyen, 2006), differences across countries are still not covered. There is a general feeling that, while intertemporal differences can be attributed to economic effects such as per capita income and to technological developments, contemporaneous differences are of mainly institutional or cultural nature. In other words: the relative stability of differences in entrepreneurial activity across countries suggests that factors other than economic ones are at play (Grilo and Thurik 2005b). In order to learn more about the relationship between culture and entrepreneurship, the guest editors of the present special issue organized a workshop with outstanding scholars in both fields - culture and entrepreneurship to see how these two phenomena are linked.

The collection of contributions of the present issue does not primarily answer questions; it is also meant to raise them. The knowledge so far is relatively eclectic and not collected in comprehensive and concise form. We are convinced that this special issue of the Journal of Evolutionary Economics provides useful and original thoughts that will encourage other scholars to further explore the topic.

The present paper is meant to open the discussion and is organized as follows. Section 2 presents three strands of theoretical literature about the entrepreneur. In section 3 we discuss the literature about country differences in entrepreneurial activities. The subsequent section 4 offers some new thoughts about the determinants of entrepreneurial attitudes and activities by testing empirically the relationship between institutional variables and the cross-country differences in the preferences for self-employment as well as in actual self-employment. Data of the 25 member states of the European Union as well as the US are used. The results of this exercise are intriguing. In this particular sample, the considered country specific cultural and institutional

See Swedberg (2000) for views from other parts of the social sciences.

See Blau (1987); Acs, Audretsch and Evans (1994); Carree, van Stel, Thurik and Wennekers (2002).

See Wennekers, van Stel, Thurik and Reynolds (2005) and Van Stel, Carree and Thurik (Thurik).

See Masuda (2006) for an analysis of Japanese regions. 
variables seem to explain the preference for entrepreneurship but not the actual entrepreneurship. In section 5, we introduce the other four contributions to this special issue.

\section{Economic theory and the level of the individual entrepreneur}

The economics literature on the role of entrepreneurship is dominated by the influence of three scholars, Schumpeter, Kirzner and Knight. The Schumpeterian tradition stresses the inherent disequilibrium nature of market dynamics. It breaks with the neo-classical approach which tended to analyze market functioning and agents' decisions as an equilibrium phenomenon and it sees entrepreneurial activity as almost identical to innovative activity. The entrepreneur is the 'persona causa' of pushing the economy out of equilibrium. In the Kirznerian tradition entrepreneurs demonstrate alertness to exploit (profit) opportunities. They are involved in a process of learning and discovery with the result that the economy is pushed back towards equilibrium. Kirznerian entrepreneurs operate in a different phase of the product life cycle than do Schumpeterian ones. The Knightian tradition emphasizes the importance of two functions of entrepreneurs: (1) providers of entrepreneurial inputs who (2) receive a return for bearing (non-calculable) risk. Hébert and Link (1989) show that these three intellectual traditions can be traced back to Cantillon's Essai sur la Nature du Commerce en Général. ${ }^{5}$ Casson (1982) and Wennekers and Thurik (1999) attempt to make a synthesis again.

The three traditions started from studying the role of entrepreneurship in the economy but contributed to a field concerned with self-employment decisions known as the theory of income choice. This field has proved useful in describing some of the factors influencing this occupational decision. In this neo-classical approach agents act as (expected)-utility maximizers taking an occupational choice decision - to become employees or entrepreneurs (self-employed) - given the utility associated with the returns accruing from the two types of activity (de Wit, 1993; Grilo and Irigoyen, 2006). This constrained optimization approach is inspired primarily by the role of an entrepreneur such as it is found in the work of Knight (1921) although the specification and the working assumptions vary according to the factor playing the key role in explaining self-employment decisions.

Knight views the entrepreneur as playing a twofold function: “(a) exercising responsible control and (b) securing the owners of productive services against uncertainty and fluctuations in their incomes". ${ }^{6}$ The first 'provider' function plays a role answering the question why different individuals make different occupational choices by emphasizing the role of entrepreneurial ability. Several authors follow this route by postulating differences across potential entrepreneurs (or firms) in terms of some form of entrepreneurial efficiency (Jovanovic, 1982 and 1994; Lucas, 1978; Murphy, Shleifer and Vishny, 1991; Holmes and Schmitz, 1990 and Lazear, 2004 and 2005). The second 'risk bearer' function gives a particular role to the presence of risk or that of risk attitudes in the occupational choice decision. Kihlstrom and Laffont (1979) and Parker (1996 and 1997) show that the degree of risk aversion and the differences in risk of the two occupational alternatives determine the occupational choice. A third aspect that has been emphasized in explaining different occupational choices is the existence of liquidity constraints. Evans and Jovanovic (1989) building upon Lucas (1978) and Jovanovic (1982) show that, under certain conditions due to capital constraints, there is a positive relationship between the probability of becoming self-employed and the assets of the entrepreneur. This influential study led to many follow up investigations of both conceptual and empirical nature (Hurst and Lusardi, 2004).

They refer to the edition of Essai sur la Nature du Commerce en Général translated by H. Higgs, 1931, London: McMillan. As quoted by Grilo and Irigoyen (2006). 
A large empirical literature has built on the insights from the occupational choice models and has sought to test the role of factors influencing self-employment decisions at the micro level. These studies attempt to explain the probability of someone being or becoming selfemployed. See Parker (2004), Blanchflower (2004) and Grilo and Thurik (2005a and 2005c) for references. Typical explanatory variables include age, gender, race, education, earnings, capital assets, previous professional experience, marital status, professional status of the parents, and scores from psychological tests. There are many other determinants of being or becoming selfemployed which are dealt with in the literature such as employment status (wage, part-time, unemployment, characteristics of the workplace), minority behavior, immigrant behavior, family firm effects and attitudinal effects (past failures, relatives with experience, confidence, knowing other entrepreneurs, opportunity perception).

\section{Country differences and the eclectic approach}

The level of entrepreneurship, expressed as the percentage of owners/managers of incorporated and unincorporated businesses relative to the labor force i.e., the rate of entrepreneurship, differs strongly across countries. ${ }^{7}$ Moreover, the percentage of nascent or young entrepreneurs differs strongly across countries. ${ }^{8}$ Lastly, also latent entrepreneurship, i.e., declared preference, varies greatly across countries. Grilo and Thurik (2006) provide a survey of European countries and the US. These differences are assumed to be related to levels of economic development in addition to demographic, cultural and institutional characteristics (Blanchflower, 2000). Differences over time seem to be dominated by economic influences whereas cross-country variations seem to be affected by cultural and institutional components (Wennekers, Uhlaner and Thurik, 2002). In particular, there is some intriguing evidence that the level of business ownership displays a U-shaped relationship when related to economic development (Blau, 1987; Acs, Audretsch and Evans, 1994; Carree, van Stel, Thurik and Wennekers, 2002). This U-shape appears also in the case of nascent entrepreneurship (Wennekers, van Stel, Thurik and Reynolds, 2005). The implication of such a U-shape is that, as economies develop, the rate of new business startups or that of nascent entrepreneurs declines until it picks up again in highly developed economies. This reversal marks the regime switch between the managed and the entrepreneurial economy (Audretsch and Thurik, 2001 and 2004).

In Figure 1 the development of the rate of entrepreneurship is given for six countries of the 23 of the Compendia data set (Van Stel, 2005). The rate of entrepreneurship is defined as the percentage of the number of non-agricultural business owners (including unincorporated and incorporated self-employed but excluding unpaid family workers) in the total labor force. We clearly observe not only the U-shaped development over time but also the persistent differences between the countries. ${ }^{9}$ Whereas economic development is often given as the main driver of the U-shape, the persistent differences between countries point at non-economic causes such as cultural ones which have a tendency to remain relatively stable over time. The further investigation of this latter view is the primary incentive of the present special issue of the Journal of Evolutionary Economics.

For instance, see Van Stel (2005) for data of 23 OECD countries over a recent period of some thirty years.

See Reynolds, Bosma, Autio, Hunt, de Bono, Servais, Lopez-Garcia and Chin (2005) for a survey of the Global Entrepreneurship Monitor data set.

9 Another phenomenon which is underresearched is the rise is variance of the rate of entrepreneurship until 1992 - it more than doubled in the period 1972-1992 for the 23 OECD countries of the Compendia set - and its stabilization afterwards. 


\section{Figure 1: rate of entrepreneurship in six OECD countries}

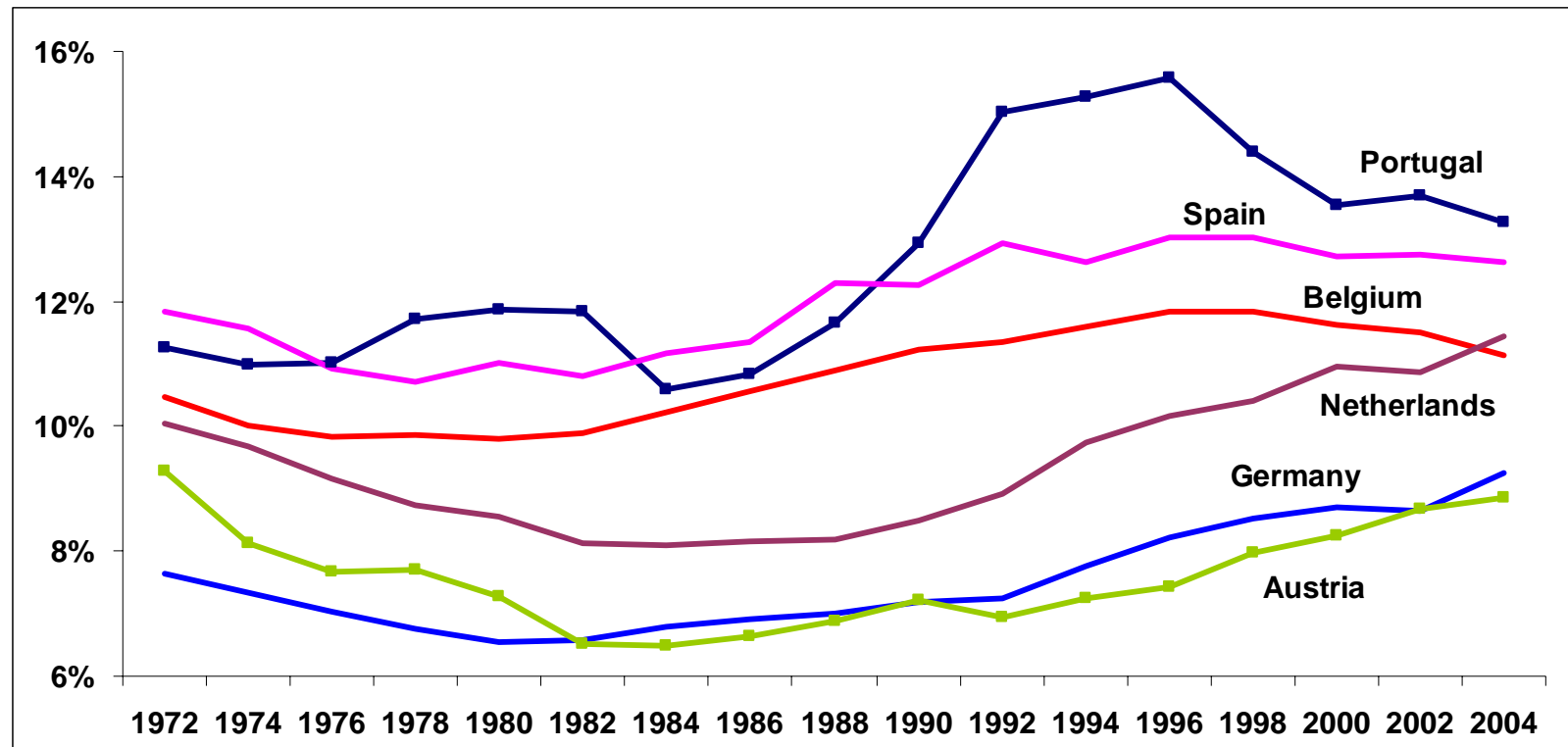

Source: Compendia 2004.2. See Van Stel (2005).

Whereas the explanation of the individual proclivity towards entrepreneurship is dominated by income choice models, the explanation of the rate of entrepreneurship clearly belongs to the realm of multidisciplinary investigations. See Verheul, Audretsch, Wennekers and Thurik (2002) for such an 'eclectic' framework and Wennekers, Uhlaner and Thurik (2002) as well as Audretsch, Grilo and Thurik (2007b) for updates. Other investigations also use the 'eclectic' approach. ${ }^{10}$ Typically, these eclectic investigations attempt to bring together elements from different fields and levels of analysis.

The multidimensionality of entrepreneurship is reflected both in the way it is defined and measured. Reference is often made to definitions of entrepreneurship from economics (based on both the functions of the entrepreneur and the perception of economic opportunities and innovation) and to those from the managerial world, where entrepreneurship is referred to as a way of managing. This discrimination is also referred to as that between occupational and behavioral entrepreneurship (Sternberg and Wennekers, 2005: 193). As regards measurement, two approaches are suggested. Business ownership and self-employment are considered as equivalent to entrepreneurship and can be the basis for static indicators (Wennekers, Uhlaner and Thurik, 2002). From a dynamic perspective, the proposed measures of entrepreneurship are based on latent (preference), nascent and start-up activity (Grilo and Irigoyen, 2006). In Verheul, Wennekers, Audretsch and Thurik (2002) for instance, the framework distinguishes various disciplines, several levels of analysis (micro, meso and macro), and classifies the explanatory factors into two categories - supply and demand side. From the demand side the framework focuses on factors that influence the industrial structure and the diversity of consumers' tastes, such as technological development, globalization and standard of living developments. The supply side looks into various structural characteristics of the population and

10 See the contributions by Busenitz, Gomez and Spencer (2000), Stevenson and Lundström (2001) and by the Global Entrepreneurship Monitor teams (Reynolds, Hay and Camp, 1999; Reynolds, Bygrave, Autio, Cox, and Hay, 2002 and Acs, Arenius, Hay and Minniti 2005). 
the way these affect the likelihood of someone becoming an entrepreneur. Population growth, urbanization rate, age structure, participation of women in the labor market, income levels and unemployment are examples of such factors. While the supply and demand sides refer to the macro level, the eclectic framework also integrates the decision-making process explaining how and why individuals make the choice to become self-employed as opposed to other job opportunities in terms of risks and rewards of different occupational alternatives - along the lines discussed above.

Other than personal characteristics, the environment in which business is conducted plays a crucial role in fostering or weakening entrepreneurial activities both in terms of firm creation, of firm expansion and of implementation of process, product and management innovation within a firm. From a policy point of view these "framework conditions" are the aspects that offer wider scope for action. Issues such as the fiscal environment, labor market regulations, administrative complexities, intellectual property rights, bankruptcy law, education and skill upgrading, etc. are understandably crucial in determining the entrepreneurial dynamism of an economy. 11

Cultural aspects are assumed to shape the environment in which business is conducted. From a research point of view there is a paucity of contributions dealing with cultural influences. Hofstede (2001, p.9) refers to culture as "the collective programming of the mind that distinguishes the members of one group or category of people from another.” This programming typically happens early in life (Hofstede, 1980; Barnouw, 1979) and leads to behavioral patterns which continue over time and hence set the cultural context (Hofstede, 1980; Mueller and Thomas, 2001). Psychological research shows links between values, beliefs and behavior. Hence, it is plausible that differences in culture, in which individual values and beliefs are imbedded, influence a wide range of behaviors including the decision to become self-employed rather than to work for others (Mueller and Thomas, 2001). Using this logic, several studies explore the relationship between various aspects of culture and entrepreneurial behavior across cultures (Busenitz, Gómez and Spencer, 2000; Davidsson, 1995; Huisman, 1985; Lee and Petersen, 2000; McGrath and MacMillan, 1992; Mueller and Thomas, 2001; Tiessen, 1997; Noorderhaven, Wennekers, Thurik and van Stel, 2004). Basically, there are three views (Wennekers, 2006).

The first view is the 'aggregate psychological trait' explanation of entrepreneurship. The idea is that if a society contains more people with 'entrepreneurial values', more people will become entrepreneurs (Davidsson, 1995; Uhlaner and Thurik, 2007). Davidsson refers to McClelland (1961) and other proponents of the individualistic view of culture. A second view refers to the degree of 'legitimation' or 'moral approval' of entrepreneurship within a culture (Etzioni, 1987). This view claims that a higher overall level of 'legitimation' of entrepreneurship implies wide ranging manifestations including more attention for entrepreneurship within the educational system, a higher social status of entrepreneurs and more tax incentives to encourage business start-ups. Obviously, this results in higher demand for and supply of entrepreneurship (Etzioni, 1987). The third view is the 'push' explanation of entrepreneurship. This view starts from the assumption that variation in entrepreneurship is based upon differences in values and beliefs between the population as whole and potential entrepreneurs. It argues that, in a predominantly non-entrepreneurial culture, a clash of values between these groups may drive the latter away from the average (non-entrepreneurial) organization and into self-employment (Baum, Olian, Erez, Schnell, Smith, Sims, Scully and Smith, 1993; Noorderhaven, Wennekers, Thurik and van Stel, 2004). The second 'legitimation' view is the reverse of the third 'push' view.

11 See Stevenson and Lundström (2001) and Audretsch, Grilo and Thurik (2007a) for surveys of entrepreneurship policies. 
Aspects of culture are difficult to model. None of the three views is easy to capture in terms of variables. Therefore, in the following section, we decide to use proxies for culture which can be expressed by more directly observable variables, such as social spending, regulation, political organization, etc. Thereby, we assume that individuals are trying to meet social norms rather than to generally distinguish themselves from their countrymen. In doing so we concentrate on the first two views. Cross-country differences are assumed to be based on differences in cultural and/or related institutional aspects. In this issue Koenig, Steinmetz, Frese, Rauch and Wang (2007) refer to these aspects as cultural orientations, i.e., manifestations of culture at the individual as opposed to manifestations at the aggregate level. They introduce a new scale measuring cultural orientations of business owners since they feel that existing cultural orientation scales are not suitable for business owners. The scenario based approach as opposed to the usual Likert based approach is certainly new in the world of economic analyses.

\section{An example of the influence of culture}

As we have seen from the literature on the determinants of entrepreneurship, regularities exist which hold for many individuals across countries. In a recent analysis Grilo and Thurik start from this assumption and use individual variables such as gender, age, education level and whether parents are self-employed, measures of risk tolerance, internal and external locus of control and four perceptions of 'obstacles' to explain what they call entrepreneurial energy (Grilo and Thurik, 2006). This energy is captured in two dimensions: latent and actual entrepreneurship. In other words: to want to be entrepreneur and to be entrepreneur. Latent entrepreneurship is measured using the declared preference for self-employment over employment. They use Eurobarometer survey data (some 8000 respondents) from the 25 member states of the EU as well as the US for the year 2004. ${ }^{12}$ The set of explanatory variables used does not include country-specific macro-economic or cultural phenomena. Country differences are controlled for using country dummies. Observing the coefficients of the country dummies Grilo and Thurik conclude that in comparison with the US, European citizens have a lower preference for self-employment. ${ }^{13}$ This lower preference level has not been explained so far nor are differences between the coefficients explored. Observing the coefficients of the country dummies of the equation explaining actual entrepreneurship Grilo and Thurik found no clear regularities. $^{14}$

In the present study we will use the coefficients of these 26 country dummies in a confrontation with some country-specific cultural and macro-economic aspects since, in addition to personal variables, these country-specific effects may play an important role for the decision to (want to) be entrepreneur. By culture we understand a broad idea of cultural as well as institutional constraints of human behavior. ${ }^{15}$ As these constraints differ from country to country, they may contribute to the explanation of different degrees of entrepreneurial energy across countries.

12 Grilo and Thurik (2006) follow the setup of Grilo and Irigoyen (2006) while specific attention is given to differences between the eight former communist member states and the 17 other EU member states. The most striking result is the higher influence of risk tolerance in shaping both latent and actual entrepreneurship in transition economies relative to market economies.

13 The dummy coefficients in the 'preference' equation are negative for all 25 European countries and almost always significant (with the exception of four countries: Cyprus, Ireland, Lithuania and Portugal).

14 The dummy coefficients in the 'actual' equation are negative for six European countries (France, Luxembourg, Portugal Malta, Latvia and Slovenia) but significantly only for France and Luxembourg. They are positive for all remaining 19 countries but significantly only for Belgium, Greece, Finland, Cyprus, Czech Republic, Hungary, Poland and Slovakia.

15 Here we depart from the North (1994) approach where institutions are defined to include culture but where a distinction between the two is also made (formal constraints such as rules, laws and constitutions versus informal constraints such as norms of behavior, conventions, etc). 
The variables to be explained in our analysis are the coefficients of the country dummies for both the preference for entrepreneurship (PREFER) and actual entrepreneurship (ACTUAL), computed with the US as benchmark. A negative value shows a lower inclination relative to the US to (want to) be an entrepreneur. The coefficients ${ }^{16}$ can be seen as measures of nation-wide entrepreneurship energy corrected for individual effects. Below we refer to these variables as 'corrected' actual and preference for entrepreneurship.

As exogenous variables we use the following four variables. First, we use the regulatory dimension (OREF) from the 'Frazer' index of economic freedom as defined by Gwartney, Lawson and Garzke (2005). ${ }^{17}$ Only regulatory aspects are used here because they affect individual decisions about self-employment; they reflect cultural aspects well and they are sufficiently different across countries. In addition, we employ a post communism dummy (PCD) to incorporate historical influences on role models and institutions, the life expectancy index (LEI) taken from the Human Development Report (UNDP, 2005), as well as public and private spending for health care as share of GDP (HEALTH) also taken from the Human Development Report. HEALTH can be used as proxy for social spending.

Given that our two variables to be explained (PREFER and ACTUAL) represent the for individual variables 'corrected' country differences in entrepreneurial energy, our hypotheses are the following. PREFER and ACTUAL are negatively influenced by OREF. In other words: the higher the degree of regulation the lower the for individual variables 'corrected' entrepreneurial energy. We expect the for individual variables 'corrected' entrepreneurial energy to be lower in post communist countries, the reason being that individuals are simply less used to entrepreneurial activities when raised in communist countries. ${ }^{18}$ Life expectancy (LEI) is also expected to have a negative impact on the for individual variables 'corrected' entrepreneurial energy. A high life expectancy can be interpreted as a proxy for security (Freytag and Vietze 2006). High security is negatively correlated with the incentive to become an entrepreneur. Finally, HEALTH can take two directions of influence: first high social spending discourages entrepreneurs because of their high costs (negative sign), second, high social spending can be seen as a sign for high solidarity within a country. It then may encourage individuals to take risks (positive sign). We expect the first interpretation as more likely in European welfare states. We will not make a priori assumptions on the difference of the influence on PREFER and ACTUAL. ${ }^{19}$

Table 1 presents the correlations between all dependent and independent variables. We see that life expectancy as well as percentage public and private spending for health care are lower in post communist countries and that, indeed, these two variables are positively correlated. The 'corrected' preference for entrepreneurship and the 'corrected' actual entrepreneurship show a low negative correlation. The former variable is lower in post communist countries whereas the second is higher.

16 The coefficients are taken from Table 3, columns 2 and 5, respectively, in Grilo and Thurik (2006, 90-91). For the US we take a value of zero since it is the benchmark country.

17 The other dimensions of the 'Frazer' index are: size of government (expenditures, taxes and enterprises); legal structure and security of property rights; access to sound money; and freedom to trade internationally. They are not used in the present analysis.

18 Consequently, this effect is expected to vanish slowly over time.

19 From Grilo and Irigoyen (2006) and Grilo and Thurik (2005b and 2006) we know that differences in the effects on the preference for entrepreneurship and actual entrepreneurship can be sizable. 
Table 1: correlation matrix

\begin{tabular}{|l|l|l|l|l|l|l|}
\hline & PREFER & ACTUAL & OREF & PCD & LEI & HEALTH \\
\hline PREFER & 1 & & & & & \\
\hline ACTUAL & -.25 & 1 & & & & \\
\hline OREF & -.07 & -.30 & 1 & & & \\
\hline PCD & -.33 & .20 & -.22 & 1 & & \\
\hline LEI & .09 & -.14 & .01 & $-.89^{*}$ & 1 & \\
\hline HEALTH & -.03 & -.08 & -.17 & $-.64^{*}$ & $.71^{*}$ & 1 \\
\hline \multicolumn{7}{rl}{ Note: * significant at the $1 \%$ level }
\end{tabular}

Table 2: the influence of some cultural variables on the preference for entrepreneurship and actual entrepreneurship in the $25 \mathrm{EU}$ member states and the US

\begin{tabular}{|l|l|l|l|l|}
\hline $\begin{array}{r}\text { dependent } \\
\text { variables }\end{array}$ & \multicolumn{2}{|c|}{$\begin{array}{r}\text { PREFER } \\
\text { (latent entrepreneurship) }\end{array}$} & \multicolumn{2}{c|}{$\begin{array}{c}\text { ACTUAL } \\
\text { (actual entrepreneurship) }\end{array}$} \\
\hline $\begin{array}{l}\text { exogenous } \\
\text { variables }\end{array}$ & coefficient & t-statistic & coefficient & t-statistic \\
\hline constant & 7.31 & 4.13 & 1.32 & 0.38 \\
\hline OREF & -0.22 & -3.94 & -0.12 & -0.99 \\
\hline PCD & -0.91 & -6.26 & 0.03 & 0.09 \\
\hline LEI & -6.54 & -3.45 & -0.48 & -0.15 \\
\hline HEALTH & -0.06 & -1.77 & -0.00 & -0.03 \\
\hline R-squared & \multicolumn{2}{|c|}{0.53} & \multicolumn{2}{c|}{0.12} \\
\hline observations & \multicolumn{2}{|c|}{26} & \multicolumn{2}{c|}{} \\
\hline
\end{tabular}

Note: White heteroskedasticity-consistent standard errors are used

The simple linear regression results are given in Table 2 and show that while ACTUAL cannot be adequately explained by the four variables, PREFER can. All coefficients explaining the 'corrected preference' for entrepreneurship are significant at the 1 per cent level, except for HEALTH, which is significant at the 10 per cent level. Their signs are in line with what we expected: regulation has a negative effect on the 'corrected' preference for entrepreneurship and so has the fact that a country has communist history. Life expectancy and percentage public and private spending for health also have a significantly negative impact on latent entrepreneurship.

We report further about four tests we performed. First, we leave out PCD since it correlates with LEI and HEALTH. The results show that the post-communist dummy is highly relevant; all other variables become insignificant. Second, we used ACTUAL in the PREFER regression and vice versa. As could be inferred from the low negative correlation between the variables they both have negative coefficients in the respective specifications with a significance below the 5 per cent level but their presence did not affect the (significance of the) coefficients of the other variables. Third, we used the general index of economic freedom instead of OREF. The results generally remain unaffected, only HEALTH becomes insignificant in the PREFER relation and obviously the R-squared drops to $=0.36$. Lastly, we replaced PREFER and ACTUAL by the uncorrected percentages of the preference for entrepreneurship (PRE) and the actual entrepreneurship (ACT) which can be computed from Table 1 of Grilo and Thurik (2006, p. 87). The results show that the explanation of the 
preference specification drops heavily from R-squared $=.53$ to $=.30$ while the coefficients of the actual specification remain insignificant. ${ }^{20}$

The most intriguing result remains that country specific (cultural and macro-economic) variables seem to explain the preference for entrepreneurship but not the actual entrepreneurship. It is tempting to assume that the actual decision is determined rather by hard economic factors such as tax rates, direct regulatory burden and the level of unemployment (Van Stel, Storey and Thurik, 2007). By contrast, the preference for self-employment can be traced back to some cultural variables.

Obviously, we cannot rule out reversed causality. We have assumed and could show that cultural aspects constrain the behavior and preferences of would be entrepreneurs. However, the question is whether or not our direction of causality is correct. It may be that the preference for self-employment has (also) an impact on the cultural setting in a country. As we cannot settle this interesting matter, we do see future research potential. Part of it is addressed in the special issue.

\section{This issue}

This special issue of the Journal of Evolutionary Economics entitled "Entrepreneurship and Culture" deals with some questions related to cultural aspects of entrepreneurship. Given the newly developed interest in institutional aspects of economic interaction, the focus on cultural aspects with respect to entrepreneurship is justified if not overdue. Moreover, above we argued that given the interest in the determinants of entrepreneurship there is a lack of cultural elements.

This issue contains four papers which all take a different perspective on the topic. It starts with two papers discussing the origins of entrepreneurship, thereby distinguishing between individual and political sources. These papers analyze OECD countries and employ crosscountry methods. First, Wennekers, van Stel, Thurik and Noorderhaven discuss whether uncertainty avoidance is a source of entrepreneurship. An occupational choice model is introduced to support the macro-level regression analysis using pooled macro data for 1976, 1990 and 2004 and controlling for several economic variables. It yields evidence that uncertainty avoidance is positively correlated with the prevalence of business ownership. A restrictive climate of large organizations in high uncertainty avoidance countries seems to push individuals striving for autonomy towards self-employment. For 2004 alone this positive correlation is no longer found, indicating that a compensating pull of entrepreneurship in countries with low uncertainty avoidance may have gained momentum in recent years. Furthermore, an interaction term between uncertainty avoidance and GDP per capita in the pooled panel regressions shows that the historically negative relationship between GDP per capita and the level of business ownership is substantially weaker for countries with lower uncertainty avoidance. This suggests that rising opportunity costs of self-employment play a less important role in this cultural environment, or are being compensated by increasing entrepreneurial opportunities.

Second, Uhlaner and Thurik focus on post-materialism as a source for entrepreneurship using Inglehart's four item post-materialism index. A distinction is made between nascent entrepreneurship, new business formation and a combination of the two, referred to as total entrepreneurial activity, as defined within the Global Entrepreneurship Monitor (GEM). Their set-up is also tested for the rate of established businesses. A set of economic, demographic and

20 The correlation coefficient between PRE and ACT is positive but low (.24) while that between PREFER and PRE is .91 and that between ACTUAL and ACT is .82. 
social factors is included to investigate the independent role postmaterialism plays in predicting entrepreneurial activity levels. In particular, per capita income is used to control for economic effects. Education rates at both secondary and tertiary levels are used as demographic variables. Finally, life satisfaction is included to control for social effects. Data from 27 countries (GEM, World Values Survey and other sources) are used to test the hypotheses. Findings confirm the significance of postmaterialism in predicting total entrepreneurial activity and, more particularly, new business formation rates. These two papers show that entrepreneurship is definitely influenced by cultural aspects.

After discussing cultural determinants of entrepreneurship, the issue proceeds by analyzing the effects culture has on the success of entrepreneurs in creating growth. Beugelsdijk looks at 54 European regions. He develops a measure for entrepreneurial attitude and uses this as exogenous variable for innovativeness (patents per capita) and growth (GRP per capita) in the regions. A measure of 'entrepreneurial culture' is developed using individual value patterns of entrepreneurs and non-entrepreneurs. Extensive robustness analysis suggests that differences in economic growth in Europe can indeed be explained using this newly developed variable, albeit in an indirect way. Differences in growth are partly due to differences in regional innovativeness which can be explained by differences in entrepreneurial culture. Culture affects growth through the intermediating mechanism of innovativeness.

Finally, Koenig, Steinmetz, Frese, Rauch and Wang measure cultural orientations of business owners using a methodological setup. They hold that whenever research is oriented towards the individual level, that is, whenever individual business owners are studied, researchers should measure cultural orientations at the individual level instead of culture at the aggregate level. They develop scales measuring cultural orientations of business owners using dimensions such as uncertainty avoidance, power distance, collectivism, assertiveness, future orientation, humane orientation and performance orientation. Scenario-based scales are introduced measuring cultural orientations of business owners. These orientations are manifested in the practices business owners apply in their businesses. Scenario-based measurement (as opposed to common Likert item-based measurement) is certainly new in the world of economic analyses. The scales have been validated on some 450 Chinese and German business owners and proven to be invariant across the two countries. Full configural, full metric, and partial scalar invariance are supported as well as partial factor variance and partial error variance invariance. This suggests that they hold cross-country validity and allow for meaningful cross-cultural comparisons.

Early versions of these papers have been presented on a workshop, the editors of the present issue organized jointly with Lorraine Uhlaner at the Max Planck Institute of Economics in Jena, February 7, 2005. We are grateful to our host who did not only provide us with facilities but also covered the costs for the entire enterprise. We are also grateful to those participants to the workshop whose papers are not covered in this issue as well as to the referees whose work contributed enormously to the quality of the papers in the special issue. 


\section{References}

Acs, Z.J., D.B. Audretsch and D.S. Evans, 1994, The determinants of variations in self-employment rates across countries and over time, Discussion Paper 871, London: Centre for Economic Policy Research.

Acs, Z.J., P. Arenius, M. Hay and M. Minniti, 2005, Global Entrepreneurship Monitor: 2004 Executive Report, Babson Park, MA: Babson College and London: London Business School.

Beugelsdijk, Sj., 2007, Entrepreneurial culture, regional innovativeness and economic growth, Journal of Evolutionary Economics, this issue.

Audretsch, D.B., I. Grilo and A.R. Thurik, 2007a, Handbook of Entrepreneurship Policy, Cheltenham, UK and Brookfield, US: Edward Elgar Publishing, forthcoming.

Audretsch, D.B., I. Grilo and A.R. Thurik, 2007b, Explaining entrepreneurship and the role of policy: a framework, in: D.B. Audretsch, I. Grilo and A.R. Thurik (eds), Handbook of Entrepreneurship Policy, Cheltenham, UK and Brookfield, US: Edward Elgar Publishing, forthcoming.

Audretsch, D.B. and A.R. Thurik, 2001, What is new about the new economy: sources of growth in the managed and entrepreneurial economies, Industrial and Corporate Change 10(1), 25-48.

Audretsch, D.B. and A.R. Thurik, 2004, The model of the entrepreneurial economy, International Journal of Entrepreneurship Education 2(2), 143-166.

Barnouw, V., 1979, Culture and Personality, Homewood, IL: Dorsey Press.

Baum, J.R., J.D. Olian, M. Erez, E.R. Schnell, K.G. Smith, H.P. Sims, J.S. Scully and K.A. Smith, 1993, Nationality and work role interactions: a cultural contrast of Israeli and U.S. entrepreneurs' versus managers' needs, Journal of Business Venturing 8(6), 499-512.

Blanchflower, D.G., 2000, Self-employment in OECD countries, Labor Economics 7(5), 471-505.

Blanchflower, D.G., 2004, Self-employment: more may not be better, Swedish Economic Policy Review 11(2), 15-73.

Blau, D., 1987, A time-series analysis of self-employment in the United States, Journal of Political Economy 95(3), 445-467.

Busenitz, L.W., Gomez, C. and J.W. Spencer, 2000, Country institutional profiles: unlocking entrepreneurial phenomena, Academy of Management Journal 43(5) 994-1003.

Carree, M.A., A.J. van Stel, A.R. Thurik and A.R.M. Wennekers, 2002, Economic Development and Business Ownership: an Analysis Using Data of 23 OECD Countries in the Period 1976-1996, Small Business Economics 19(3), 271-290.

Casson, M.C., 1982, The Entrepreneur: an Economic Theory, Oxford: Martin Robertson.

Davidsson, P., 1995, Culture, structure and regional levels of entrepreneurship, Entrepreneurship and Regional Development 7(1), 41-62.

Davidsson, P., 2004. Researching Entrepreneurship. International Studies in Entrepreneurship, Boston etc: Springer Science Inc.

Etzioni, A., 1987, Entrepreneurship, adaptation and legitimation, Journal of Economic Behavior and Organization 8, 175-189.

Evans, D.S. and B. Jovanovic, 1989, An estimated model of entrepreneurial choice under liquidity constraints, Journal of Political Economy, 97(4), 808-827.

Koenig, Ch., H. Steinmetz, M. Frese, A. Rauch and Z-M. Wang 2007, Scenario-based scales measuring cultural orientations of business owners, Journal of Evolutionary Economics, this issue.

Freytag, A. and Chr. Vietze, 2006, International tourism, development and biodiversity: first evidence, Jenaer Schriften zur Wirtschaftswissenschaft, 11/2006.

Grilo, I. and J.M. Irigoyen, 2006, Entrepreneurship in the EU: to wish and not to be, Small Business Economics 26(4), 305-318.

Grilo, I. and A.R. Thurik, 2005a, Determinants of entrepreneurial engagement levels in Europe and the US, Papers on Entrepreneurship, Growth and Public Policy no 25-2005, Max Planck Institute of Economics, Jena, Germany.

Grilo, I. and A.R. Thurik, 2005b, Latent and actual entrepreneurship in Europe and the US: some recent developments, International Entrepreneurship and Management Journal 1(4), 441-459.

Grilo, I. and A.R. Thurik, 2005c, Entrepreneurial engagement levels in the European Union, International Journal of Entrepreneurship Education, 3(2), 143-168. 
Grilo, I. and A.R. Thurik, 2006, Entrepreneurship in the old and the new Europe, in: E. Santarelli (ed), Entrepreneurship, Growth and Innovation, Berlin: Springer Verlag, 75-103.

Gwartney, J., R. Lawson and E. Gartzke, 2005, Economic Freedom in the World - 2005 Annual Report, Fraser Institute, Vancouver. See http://www.fraserinstitute.ca/shared/readmore.asp?sNav=pb\&id=789

Hébert, R.F. and A.N. Link, 1989, In search of the meaning of entrepreneurship, Small Business Economics 1(1), 39-49.

Hofstede, G., 1980, Culture's Consequences: International Differences in Work-Related Values, Beverly Hills, CA: Sage Publications.

Hofstede, G., 2001, Culture's Consequences; Comparing Values, Behaviors, Institutions and Organizations Across Nations, $2^{\text {nd }}$ edition, Thousand Oaks, etc: Sage Publications.

Holmes, Th.J. and J.A. Schmitz Jr., 1990, A theory of entrepreneurship and its application to the study of business transfers, Journal of Political Economy, 98(2), 265-294.

Huisman, D., 1985, Entrepreneurship: economic and cultural influences on the entrepreneurial climate, European Research 13(4), 10-17.

Hurst, E. and A. Lusardi, 2004, Liquidity constraints, household wealth and entrepreneurship, Journal of Political Economy 112(2), 319-347.

Jovanovic, B., 1982, Selection and the evolution of industry, Econometrica 50(3), 649-670.

Jovanovic, B., 1994, Firm formation with heterogeneous management and labor skills, Small Business Economics 6(3), 185-191.

Kihlstrom, R. and J.-J. Laffont, 1979, A general equilibrium entrepreneurial theory of the firm based on risk aversion, Journal of Political Economy, 87(4), 719-748.

Knight, F.H., 1971, Risk, Uncertainty, and Profit, The University of Chicago Press, originally published in 1921 by Houghton Mifflin Company.

Koenig, Ch, H. Steinmetz, M. Frese, A. Rauch and Zh-M. Wang, 2007, Scenario-based measuring cultural orientations of business owners, Journal of Evolutionary Economics, this issue.

Lazear, E.P., 2004, Balanced skills and entrepreneurship, American Economic Review 94(2), 208-211.

Lazear, E.P., 2005, Entrepreneurship, Journal of Labor Economics 23(4), 649-680.

Lee, S. M. and S. J. Peterson, 2000, Culture, entrepreneurial orientation, and global competitiveness, Journal of World Business 35(4), 401-416.

Lucas, R., 1978, On the size distribution of business firms, Bell Journal of Economics 9(3), 508-523.

Masuda, T., 2006, The determinants of latent entrepreneurship in Japan, Small Business Economics, 26(3), 227-240.

McGrath, R. G. and I. C. MacMillan, 1992, More like each other than anyone else?: cross-cultural study of entrepreneurial perceptions, Journal of Business Venturing 7(5), 419-429.

McClelland, D. C., 1961, The Achieving Society. Princeton, NJ: Van Nostrand.

Mueller, S. L. and A. S. Thomas, 2001, Culture and entrepreneurial potential: a nine country study of locus of control and innovativeness, Journal of Business Venturing 16(1), 51-75.

Murphy, K.M., Shleifer, A. and R.W. Vishny, 1991, The allocation of talent: implications for growth, Quarterly Journal of Economics 106(2), 503-530.

Noorderhaven, N.G., A.R.M. Wennekers, A.R. Thurik and A. van Stel, 2004, Self-employment across 15 European countries: the role of dissatisfaction, Entrepreneurship: Theory and Practice 29(1), 447466.

North, D.C., 1994, Economic performance through time, American Economic Review 84(3), 359-368.

Parker, S.C., 1996, A time-series model of self-employment under uncertainty, Economica 63, 459-475.

Parker, S.C., 1997, The effects of risk on self-employment”, Small Business Economics, 9(6), 515-522.

Parker, S.C., 2004, The Economics of Self-Employment and Entrepreneurship, Cambridge: Cambridge University Press.

Reynolds, P.D., N. Bosma, E. Autio, S. Hunt, N. de Bono, I. Servais, P. Lopez-Garcia and N. Chin, 2005, Global entrepreneurship monitor: data collection design and implementation 1998-2003, Small Business Economics 24(3), 205-231.

Reynolds, P.D., Bygrave, W.D., Autio, E., Cox, L.W. and M. Hay, 2002, Global Entrepreneurship Monitor, 2002 Executive Report, Babson College, London Business School and Kauffman Foundation. 
Reynolds, P.D., M. Hay and S.M. Camp, 1999, Global Entrepreneurship Monitor: 1999 Executive Report, Babson College, London Business School and the Kauffman Center for Entrepreneurial Leadership.

Sternberg, Rolf and Sander Wennekers, 2005, Determinants and effects of new business creation; investigations using Global Entrepreneurship Monitor data, Small Business Economics, 24(3), 193203.

Swedberg, R., 2000, Entrepreneurship; The Social Science View, Oxford: Oxford University Press.

Stevenson, L. and A. Lundström, 2001, Patterns and trends in entrepreneurship/SME policy and practice in ten economies, Entrepreneurship Policy for the Future Series, Vol. 3, Swedish Foundation for Small Business Research.

Tiessen, J. H. 1997, Individualism, collectivism, and entrepreneurship: a framework for international comparative research, Journal of Business Venturing 12(5), 367-384.

Uhlaner, L.M. and A.R. Thurik, 2007, Postmaterialism influencing total entrepreneurial activity across nations, Journal of Evolutionary Economics, this issue.

UNDP, 2005, Human Development Report, United Nations, New York. See http://hdr.undp.org/statistics/data/.

Van Stel, A., 2005, COMPENDIA: Harmonizing business ownership data across countries and over time, International Entrepreneurship and Management Journal 1(1), 105-123.

Van Stel, A., M.A. Carree and A.R. Thurik, 2005, The effect of entrepreneurial activity on national economic growth, Small Business Economics 24(3), 311-321.

Van Stel, A., D. Storey and A.R. Thurik, 2007, The effect of business regulations on nascent and young business entrepreneurship, Small Business Economics, forthcoming.

Verheul, I., S. Wennekers, D. Audretsch and A.R. Thurik, 2002, An eclectic theory of entrepreneurship: policies, institutions and culture, in: D.B. Audretsch, A.R. Thurik, I. Verheul and A.R.M. Wennekers (eds), Entrepreneurship: Determinants and Policy in a European-US Comparison, Boston/Dordrecht: Kluwer Academic Publishers, 11-81.

Wennekers, A.R.M., 2006, Entrepreneurship at Country level: Economic and Non-Economic Determinants, PhD thesis, Rotterdam: Erasmus Research Institute of Management (ERIM).

Wennekers, A.R.M. and A.R. Thurik, 1999, Linking entrepreneurship and economic growth, Small Business Economics 13(1), 27-55.

Wennekers , A.R.M., L. Uhlaner, and A.R. Thurik, 2002, Entrepreneurship and its conditions: a macro perspective, International Journal of Entrepreneurship Education 1(1), 25-64.

Wennekers, S., A. van Stel, R. Thurik and P. Reynolds, 2005, Nascent entrepreneurship and the level of economic development, Small Business Economics 24(3), 293-309.

Wennekers, S., R. Thurik, A. van Stel, and N. Noorderhaven, 2007, Uncertainty avoidance and the rate of business ownership across 21 OECD countries, 1976-2004, Journal of Evolutionary Economics, this issue.

Wit, G. de (1993), Models of self-employment in a competitive market, Journal of Economic Surveys 7(4), 367-397. 
The results of EIM's Research Programme on SMEs and Entrepreneurship are published in the following series: Research Reports and Publieksrapportages. The most recent publications of both series may be downloaded at: www.eim.net.

\section{Recent Research Reports and Scales Papers}

\begin{tabular}{|c|c|c|}
\hline $\mathrm{H} 200615$ & 2-10-2006 & $\begin{array}{l}\text { The Geography of New Firm Formation: Evidence from Independent Start-ups } \\
\text { and New Subsidiaries in the Netherlands }\end{array}$ \\
\hline H200614 & 25-9-2006 & PRISMA-K: een bedrijfstakkenmodel voor de korte termijn \\
\hline $\mathrm{H} 200613$ & 25-9-2006 & PRISMA-M: een bedrijfstakkenmodel voor de middellange termijn \\
\hline H200612 & 25-9-2006 & $\begin{array}{l}\text { PRISMA-MKB: modelmatige desaggretatie van bedrijfstakprognose naar } \\
\text { grootteklasse }\end{array}$ \\
\hline H200611 & $25-9-2006$ & PRISMA-R: modelmatige desaggregatie van bedrijfstakprognoses naar provincie \\
\hline $\mathrm{H} 200610$ & 25-9-2006 & Explaining engagement levels of opportunity and necessity entrepreneurs \\
\hline H200609 & 25-9-2006 & $\begin{array}{l}\text { The effect of business regulations on nascent and Young business } \\
\text { entrepreneurship }\end{array}$ \\
\hline H200608 & 24-8-2006 & High growth entrepreneurs, public policies and economic growth \\
\hline H200607 & $18-8-2006$ & The decision to innovate \\
\hline H200606 & $6-7-2006$ & Innovation and international involvement of dutch SMEs \\
\hline H200605 & 27-6-2006 & $\begin{array}{l}\text { Uncertainty avoidance and the rate of business ownership across } 21 \text { OECD } \\
\text { countries, 1976-2004 }\end{array}$ \\
\hline H200604 & $22-6-2006$ & The Impact of New Firm Formation on Regional Development in the Netherlands \\
\hline H200603 & 21-6-2006 & An Ambition to Grow \\
\hline H200602 & 21-6-2006 & $\begin{array}{l}\text { Exploring the informal capital market in the Netherlands: characteristics, } \\
\text { mismatches and causes }\end{array}$ \\
\hline H200601 & $22-5-2006$ & SMEs as job engine of the Dutch provate economy \\
\hline N200520 & $7-3-2006$ & High Performance Work Systems, Performance and Innovativeness in Small Firms \\
\hline N200519 & $1-2-2006$ & Entrepreneurial Culture as Determinant of Nascent Entrepreneurship \\
\hline N200518 & 26-1-2006 & $\begin{array}{l}\text { Social security arrangements and early-stage entrepreneurial activity; an empirical } \\
\text { analysis }\end{array}$ \\
\hline N200517 & $23-1-2006$ & Determinants of Growth of Start-ups in the Netherlands \\
\hline N200516 & 23-1-2006 & Entrepreneurship in the old en new Europe \\
\hline N200515 & 23-1-2006 & Entrepreneurial engagement levels in the European Union \\
\hline N200514 & 23-1-2006 & $\begin{array}{l}\text { Latent and actual entrepreneurship in Europe and the US: some recent } \\
\text { developments }\end{array}$ \\
\hline N200513 & 20-1-2006 & $\begin{array}{l}\text { Determinants of self-employment preference and realisation of women and men } \\
\text { in Europe and the United States }\end{array}$ \\
\hline N200512 & 20-1-2006 & PRISMA-K: een bedrijfstakkenmodel voor de korte termijn \\
\hline N200511 & 19-1-2006 & $\begin{array}{l}\text { Strategic Decision-Making in Small Firms: Towards a Taxonomy of } \\
\text { Entrepreneurial Decision-Makers }\end{array}$ \\
\hline N200510 & $11-1-2006$ & Explaining female and male entrepreneurship at the country level \\
\hline N200509 & $11-1-2006$ & $\begin{array}{l}\text { The link between family orientation, strategy and innovation in Dutch SMEs: a } \\
\text { longitudinal study }\end{array}$ \\
\hline N200508 & $11-1-2006$ & From nascent to actual entrepreneurship: the effect of entry barriers \\
\hline N200507 & $11-1-2006$ & $\begin{array}{l}\text { Do entry barriers, perceived by SMEs, affect real antry? Some evidence from the } \\
\text { Netherlands }\end{array}$ \\
\hline H200503 & $6-12-2005$ & The Impact of New Firm Formation on Regional Development in the Netherlands \\
\hline N200506 & $5-9-2005$ & Entrepreneurial intentions subsequent to firm exit \\
\hline N200505 & $5-9-2005$ & $\begin{array}{l}\text { The relationship between successor and planning characteristics and the success } \\
\text { of business transfer in Dutch SMEs }\end{array}$ \\
\hline H200502 & $31-8-2005$ & Product introduction by SMEs \\
\hline H200501 & $12-5-2005$ & Kosten van inhoudelijke verplichtingen voor het bedrijfsleven \\
\hline
\end{tabular}




\begin{tabular}{lrl} 
N200504 & $21-4-2005$ & Does Self-Employment Reduce Unemployment? \\
N200503 & $7-4-2005$ & Zipf's Law in Economics \\
N200502 & $31-3-2005$ & $\begin{array}{l}\text { Early-stage entrepreneurial activity in the European Union: some issues and } \\
\text { challenges }\end{array}$ \\
N200501 & $31-3-2005$ & Scale effects in HRM Research \\
H200408 & $23-12-2004$ & Aantallen ondernemers en ondernemingen \\
H200409 & $22-12-2004$ & Armoede onder zelfstandige ondernemers \\
H200407 & $9-12-2004$ & How do firms innovate? \\
H200406 & $9-11-2004$ & $\begin{array}{l}\text { Perception of competition : A measurement of competition from the perspective } \\
\text { of the firm }\end{array}$ \\
H200405 & $27-10-2004$ & Arbeidsproductiviteit in de Nederlandse dienstensector \\
H200402 & $4-10-2004$ & Verklaren en voorspellen van naleving: uitwerking van een ex ante \\
& & schattingsmethode \\
H200401 & $4-10-2004$ & Explaining variation in nascent entrepreneurship \\
H200404 & $3-9-2004$ & Academic entrepreneurship : a source of competitive advantage \\
H200403 & $14-6-2004$ & How can leaders trigger bottom-up innovation? \\
H200311 & $29-4-2004$ & Transforming an idea into a strategic decision in SMEs \\
H200310 & $16-3-2004$ & Business dynamics and employment growth: A cross-country analysis \\
H200309 & $3-3-2004$ & The National Systems of Innovation Approach and Innovation by SMEs \\
H200308 & $3-3-2004$ & Understanding the Role of Willingness to Cannibalize in New Service \\
& & Development \\
H200307 & $3-3-2004$ & Factors influencing export development of Dutch manufactured products \\
& & \\
\hline
\end{tabular}

